\title{
The Oriental Fantasy of the Empire -- the Oriental image of the Victoria
}

\section{era literature}

\author{
Lu Zuo \\ ${ }^{1}$ Henan University of Traditional Chinese Medicine 450003 \\ a email
}

Key words: Empire fantasy; Oriental; the Vitoria era literature; the Oriental image

\begin{abstract}
In the development of world literature, English literature has played a great role in promoting the development of world literature. In this paper, the English literature as a starting point for research, further from the Victorian era critical realism novels, colonial novel and popular novel three aspects discusses the image of the East Victorian literary works. Although the criticism of the real work in the performance of the exotic interest, but the role of exotic is still only play a supporting role. In the works of colonial novels, more and more double understanding in the treatment of exotic customs reflects, which also makes the eastern style of the colonial novels reflect more fictional elements. But in popular literature, it shows more interest in the East.
\end{abstract}

\section{Introduction}

From the time dimension, in the development of English literature, Vitoria period is a glorious period in the history of English literature which is the demand of the development of the times of this period and is also a special product of the combination of social and natural factors. Victorian literature reflection the state of British society at that time from different aspects such as romantic and realistic external, also produces many famous writers. Novel is one of the popular literature of Victorian literature, and people also advocating a more passionate and patriotic spirit pursuit in this period, Queen Victoria is representative of the spirit of the times. Whether it is the traditional romantic literary works, or with the moral and the ideal combination of literary works during the Victoria period, they are constantly emerging.

\section{The image of the East in the critical realism novel}

The British literary world has emerged a number of outstanding critical realism novelist during the Victoria period, including the famous Thackeray, Dickens, etc. This is also following the development of British Romantic poetry and another climax period in the development of the history of the British literature. The material source of critical realistic novels is usually a more prominent problem in social performance reflection to the problems existing in the British society and the social contradictions, so the occurrence of this series of novels are generally confined to the United Kingdom. Although not all readers will pay attention to the role of exotic in the works, but the writers have not ignored the role of exotic in the works. They are portrayed in some parts of the works by way of exotic, and this description is usually connected with the interests of their native land in their wrting and this description is usually connected with the interests of the local. It can't be ignored is that although there are a lot of descriptions of exotic in works, but the exotic just exists as a minor way, and will not appear in the novel as the background part, just as the plot 
development and change of the service branch content. In a certain extent only as "seasoning" in the form of existence. Usually a description of the exotic is just a band, or simply through the description of the exotic to the exotic. The basic idea is that "his country and on the far side of the territory under the novelist just as a use of tools, often for enrichment and banishment of relatively simple". But we also want to clearly see that not all of the exotic background is no objection to the arrangement in the novel, in some novels, the background is also carrying a symbol or implied role. Such as in some critical realism novels, through in the works of exotic description to express the wealth of local sources, writer exotic portrayed as a way for carrying the story of scene change, which reflects the symbolic function. For example, the exotic orient as a novel in the transfer of contradictions in the novel, through this way for the development of the novel plot designed to meet the needs of the transition.

Charles Dickens, a famous British writer, is a representative of the famous critical realistic novels of Victoria. Dickens's critical realistic novels will be the social contradictions of Britain as a source of novel creation, but he did not ignore the role of the exotic in the novel. Dickens, the American miscellanies "was by Dickens access under the premise of the United States and the American society a description, the more profound the various problems existing in American society at that time, especially in a corrupt represented. Also, Dickens has a certain obsession of the Oriental theme, oriental works of national "Arabian Nights" is one of Dickens's most like secretary, and that the classic has influenced by Dickens. "No other than Dickens has a better understanding of the Arabian Nights, in some of Dickens's works, are full of Oriental and luxuriant wealth implied." At the age of 9 of Dickens. He created the Matsa: India, Sudan, this phrase, and childhood partners together for the show. The name of the "Arabian Nights" in many famous people, such as Alibaba, Allah satin and so on have appeared in the works of Dickens. Although sometimes Dickens just east as a with a laugh in the topic of application in the novel, for example in the novel the PG $\mathrm{Mr}$ Wickham Gaiden, appeared a Mr. Potter with PG, Vic, for discussion of Chinese philosophy.

Trade between countries is becoming more and more frequent during the Victoria period which also makes the domestic family emergence decorations and things in other countries. Although these Oriental goods and food is not ordinary, but these items are more able to trigger people's imagination, so the emergence of the East with a marked era of symbolic significance. Many novels in the UK are in their own imagination, and the creation of the wealth of the East that British writer Boeme in the analysis of the local image of the United Kingdom. Specifically, it is the main way of the eastern image through the wealth and the image in the English critical realism novel. But oriental image is often in the image of the relatively fragmented and there is a piece of the image, and presents a certain symbolic effect in Dickens's works. For example, in Dickens's novel, "Dong Bei and his son," Dickens through the east to describe the items to be decorated repeatedly, which also expresses the relationship between the wealth of Dong Bei and his son and the east:

In the corner of the street stand in the wealthy East India Company, it makes people continuously to think precious fabrics, stones, tigers, elephants, like a sedan, hookah, umbrellas, palmitic, four or six carried the bridge, and the skin exposing color, sitting on the carpet of luxurious King children, their slippers front-end is high tilt.

Overall, in the critical realistic novels of Victoria, the image of the East is usually not to be rendered, but to describe the East as the edge of the United Kingdom. The East is more like a local extension for the English critical realistic novelist. But the eastern background has a larger role in the creation of the novel, at least through the description of the Oriental Imagination and further develop the writer's imagination. 


\section{The Oriental Image in the Colonial Novels}

Usually when people discuss the exotic in the literary works, the works of typical colonial ideology will be excluded. The reason for the rejection of the colonial works is that the exotic is often one of the Oriental discourse strategies of the East when study of exotic. But it has to be concerned that we are more clearly seen in the colonial novels of Vitoria in the United Kingdom. We can clearly see the exotic in the colonial novel aesthetic expectations, and exotic is also a major part of the colonial novel whether it is from the theme of the colonial novels, or in the colonial novel narrative techniques and other aspects of the analysis. "It is inspired by the role, in the same a writer and at the same time, colonial novels and exotic novels can be integrated with each other., but there appears different effects between the two ", Todorov, a famous French scholar, has made an appraisal of Pierre Loti, a famous French colonial novelist in Vitoria. Exotic is the main source of their creation for Kipling and Conrad's works. If they are not used literary creation in the process, then it means that people's understanding of literary works is one-sided. But we should also see that the application of the exotic in the process of writing is more integrated into other factors, such as economic and political, and so on. The Oriental image they embodied in the colonial novel is more based on the prejudice of the white people themselves. Their works have more or less attention to the diversity of the creation in the works of Conrad and Kipling, the representative figures of colonial novels in Vitoria period the phenomenon is more common in this kind of anxiety and the work of the instability. Wang Ning in his works, "post modernism" also expressed in the process of literary creation of the author in the process of thinking and the characteristics of the dual fuzzy. In their works in the hope to reflect the white race relative to a black and yellow race superiority, on the other hand. They are more on the identity of the self has a certain anxiety, especially the unease of imperialism.

Most writers in the United Kingdom are more inclined to the creation of colonial themes and literary works at the beginning of twentieth Century, but they have a breakthrough in the cultural differences between the East and the west, which no longer put the "western centralism" as the center of the creation of the colonial literary works. E.M. Forster is a famous writer of India novels. His works, "India", is recognized as one of the most outstanding works in twentieth Century. In Forster's works, the image of India shows a certain multidimensional nature, especially in the description of the natural landscape in India, and sometimes more messy, mysterious, and sometimes show close to the nature of the clear. Mrs. Moore had a great difference with other British people in India in A Passage to India. Mrs. Moore indulge in the natural environment of India, but Forster will be more difficult to describe the fate of Mrs. Moore and she had strange death in the process of escaping from India. In the works of Foster, for India's characterization and India's description, although want to through with sympathy in mind to look at India and Indians, and also tries to descrpiction the communication with the Indians, but the pride of the white race also makes him with the colour of prejudice.

Of course, Forster and Kipling, and other writers, he has a greater progress on the treatment of cultural differences between the West and east to a certain extent. In his work, he described the white people and the Indians, and they became friends. Indians Azez body with oriental features, when western white race face him, not only reflect the white race could not understand to oriental people, but at the same time also showed a westerners to try to communicate with it as desire. In the late period of colonial novels, also appeared such as George Howell and other writers, he in his works "shooting elephants" and "Burma years", all reflect the author's disdain for the rule of the Empire and colonial policy. 


\section{The Oriental Image in Popular Fiction}

With the development of various literature in Vitoria, popular literature also has a great development in Vitoria, and popular literary works make exotic and aesthetic taste linked together, and the creation of this kind of works is more clear in the literature works of overseas adventure themes. Robert Stevenson is the representative figure of popular literary works in Vitoria era. In his novels, he chose the background of the exotic stories, and has a very exotic. But Stevenson's literary works are more exotic as the ingredients of the works. Many scholars believe that, from Stevenson's works can be seen the exotic literary works are gradually disappearing in nineteenth century. Until the end of the 19th century, exotic has become the a outworn tradition, and through the literature more platitudes, only Conrad that literary home to will exotic give more vitality. From a social point of view, the development of exotic in the literary works also represents the British Society for the transformation of the eastern cultural interest. In addition, it shows that people's interest in literary works in Vitoria has produced some changes. Overall, in the key role of the Victorian exotic regional secular is that on the one hand to meet was British Society for Oriental adventures demand and erotic fantasy, on the other hand also need to add more atmosphere for literary works, the background of the story.

In the popular literary works of Vitoria, thriller and detective fiction is a literary style widely accepted by the world. Key objective of this kind of novel is to improve the degree of suspense works that bond to exotic, and further add to the mystery for works. The works of Collins Wilkie, "The Moonstone", a British novelist, is a typical popular literary work. Although the background is the work of the United Kingdom, but Collins Wilkie will be the opening of the work and the outcome of the work set up in the east of India. This kind of borrowing from the background of the eastern countries to become the development of the story, to further enhance the work of the extension. It can be said that Collins Wilkie's literary works, especially when the moonstones as the representative, is the eastern background is always integrated with the story of the development of the work and also provides a plot of suspense and mystery to the works. No gem represents wealth in the eastern countries, colleagues also represent a grand, is carrying the spirit of Oriental civilization. In his works, the author describes the loss of precious stones, which reflects the key to colonial aggression. From the overall perspective of the work, the plot of the ups and downs, with the characteristics of the detective series, also received the "British first detective novel" title.

\section{References}

[1] Zhenzhao Nie. Ethical Literary Criticism In Chinese [J]. Journal Of Hangzhou Normal University (Social Science Edition). 2010 (05)

[2] Xiwen Dong. Classic Literature Text Reading [J]. Forum In Fujian From The Perspective Of Intertextuality Under The Concept Of (Social Science Edition). 2010 (05)

[3] Huixia Ning. A Discussion On The Victorian British Female Literature Development Of Unspeakable Pain [J]. Journal Of Henan University Of Technology (Social Science Edition), 2010. (01)

[4] Zeng Li, Ruicui Long. British "Golden Age" Of Morality Rheological, Victorian Social Class Of The Relation Between Morality And Rheological Study On [J]. Journal Of Northeast Normal University (Philosophy And Social Sciences Edition). 2008, (06) 